\title{
Two pathways for prostaglandin F2 $\alpha$ synthesis by the primate periovulatory follicle
}

\author{
Brandy L Dozier, Kikuko Watanabe ${ }^{1}$ and Diane M Duffy \\ Department of Physiological Sciences, Eastern Virginia Medical School, 700 Olney Road, Lewis Hall, Norfolk, \\ Virginia 23507, USA and ${ }^{1}$ Graduate School of Integrated Sciences and Arts, University of East Asia, 751-8503 \\ Yamaguchi, Japan
}

Correspondence should be addressed to D M Duffy; Email: duffydm@evms.edu

\begin{abstract}
Prostaglandin E2 (PGE2) has been identified as a PG necessary for ovulation, but the ovulatory gonadotropin surge also increases PGF2 $\alpha$ levels in primate periovulatory follicles. To better understand the role of PGF2 $\alpha$ in ovulation, pathways utilized for PGF2 $\alpha$ synthesis by the primate follicle were examined. Monkeys were treated with gonadotropins to stimulate multiple follicular development; follicular aspirates and whole ovaries were removed before and at specific times after administration of an ovulatory dose of hCG to span the $40 \mathrm{~h}$ periovulatory interval. Human granulosa cells were also obtained (typically 34-36 h after hCG) from in vitro fertilization patients. PGF2 $\alpha$ can be synthesized from PGH2 via the aldo-keto reductase (AKR) 1C3. AKR1C3 mRNA and protein levels in monkey granulosa cells were low before hCG and peaked 24-36 h after hCG administration. Human granulosa cells converted PGD2 into 11 $\beta$-PGF2 $\alpha$, confirming that these cells possess AKR1C3 activity. PGF2 $\alpha$ can also be synthesized from PGE2 via the enzymes AKR1C1 and AKR1C2. Monkey granulosa cell levels of $A K R 1 C 1 / A K R 1 C 2$ mRNA was low 0-12 h, peaked at $24 \mathrm{~h}$, and returned to low levels by $36 \mathrm{~h}$ after hCG administration. Human granulosa cell conversion of $\left[{ }^{3} \mathrm{H}\right] \mathrm{PGE} 2$ into $\left[{ }^{3} \mathrm{H}\right] \mathrm{PGF} 2 \alpha$ was reduced by an AKR1C2-selective inhibitor, supporting the concept that granulosa cells preferentially express AKR1C2 over AKR1C1. In summary, the ovulatory gonadotropin surge increases granulosa cell expression of AKR1C1/AKR1C2 and AKR1C3. Both of these enzyme activities are present in periovulatory granulosa cells. These data support the concept that follicular PGF2 $\alpha$ can be synthesized via two pathways during the periovulatory interval.
\end{abstract}

Reproduction (2008) 136 53-63

\section{Introduction}

Prostaglandin (PG) production by the follicle in response to the midcycle luteinizing hormone (LH) surge is necessary for ovulation to occur. Follicular fluid concentrations of both PGE2 and PGF2 $\alpha$ peak just before the expected time of ovulation in primates as in many mammalian species (Sirois 1994, Sirois \& Dore 1997, Duffy \& Stouffer 2001). While studies with PGF2 $\alpha$ receptor knockout mice suggest that PGF2 $\alpha$ is not required for ovulation (Sugimoto et al. 1997), subfertility in mice lacking expression of the PGE2 receptor EP2 focused attention on PGE2 as the key ovulatory PG (Hizaki et al. 1999). Blockade of PG production within the follicle prevented cumulus expansion, follicle rupture, and oocyte release; restoration of periovulatory events with coadministration of the PG synthesis inhibitor and PGE2 identified PGE2 as a key mediator of ovulation in mammals (Sogn et al. 1987, Peters et al. 2004), including primates (Duffy \& Stouffer 2002). However, additional studies have demonstrated restoration of ovulation with PGF2 $\alpha$ administration (Wallach et al. 1975, Murdoch et al. 1986, Sogn et al. 1987, Janson et al. 1988), suggesting that PGF2 $\alpha$ may also play a role in ovulatory processes.
Synthesis of PGF2 $\alpha$ begins with conversion of arachidonic acid into the unstable intermediate $\mathrm{PGH} 2$ through the activity of cyclooxygenase (COX; Vane et al. 1998) (Fig. 1). PGH2 can then be converted to bioactive PGs by specific PG synthases. 11 $\alpha$-PGF2 $\alpha$ (traditionally referred to as PGF2 $\alpha$ ) can be produced from either PGH2 or PGE2; a third pathway produces $11 \beta-P G F 2 \alpha$ from $\mathrm{PGH} 2$. All enzymes that produce PGF $2 \alpha$ are members of the aldo-keto reductase (AKR) family (Nishizawa et al. 2000). PGH2 can be directly converted to PGF2 $\alpha$ by the action of AKR1C3, also known as PGF synthase (Suzuki-Yamamoto et al. 1999); this same enzyme converts PGD2 into $11 \beta$-PGF2 $\alpha$. $11 \beta$-PGF2 $\alpha$ is equipotent with PGF2 $\alpha$ in the stimulation of PGF $2 \alpha$ receptors (Sugimoto et al. 1994). Finally, two closely related enzymes, AKR1C1 and AKR1C2, function as PGE-F isomerases, which interconvert PGE2 and PGF2 $\alpha$ (Nishizawa et al. 2000).

To better understand the pathways utilized for PGF $2 \alpha$ synthesis by the primate follicle, follicular expression and activity of enzymes that can produce PGF $2 \alpha$ were assessed. Previous studies by our laboratory demonstrated that the ovulatory gonadotropin surge increases 


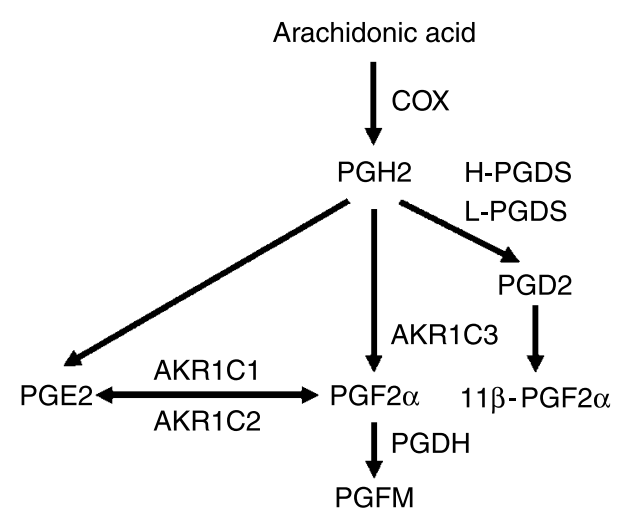

Figure 1 Three candidate pathways for the synthesis of PGF2 $\alpha$. A cyclooxygenase (COX) enzyme produces $\mathrm{PGH} 2$ from arachidonic acid. PGF $2 \alpha$ can be synthesized either directly from $\mathrm{PGH} 2$ via AKR1C3

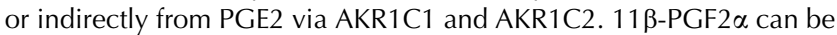
produced from PGH2 via PGD synthase (PGDS) and AKR1C3. PGF $2 \alpha$ is converted to inactive PGF metabolites (PGFM) via the 15-hydroxy PG dehydrogenase (PGDH). Adapted from Watanabe (2002).

granulosa cell expression of key enzymes required for PGE2 synthesis; increased enzyme levels parallel the rising follicular concentration of PGE2 just before ovulation (Duffy \& Stouffer 2001, Duffy et al. 2005a, $2005 b$ ). We hypothesize that the ovulatory gonadotropin surge also stimulates granulosa cell expression of enzymes necessary for the synthesis of PGF2 $\alpha$. Similarities in periovulatory processes in humans and nonhuman primates are well established (Zeleznik et al. 1994). The majority of the studies presented below were conducted using a nonhuman primate, the cynomolgus macaque. Additional experiments used human luteinizing granulosa cells to extend findings to the human periovulatory follicle.

\section{Results}

\section{Follicular fluid PGF2 $\alpha$, PGFM, and 11 $\beta$-PGF2 $\alpha$ concentrations}

Follicular fluid contained measurable concentrations of PGF2 $\alpha$ throughout the periovulatory interval (Fig. 2). Similar to our previous report of PGF2 $\alpha$ levels in rhesus monkey follicular fluid (Duffy \& Stouffer 2001) and PGE2 levels in cynomolgus monkey follicular fluid (Duffy et al. 2005c), levels of PGF2 $\alpha$ in follicular fluid of cynomolgus macaques were lowest before $(0 \mathrm{~h}) \mathrm{hCG}$ administration, rose slightly by $12-24 \mathrm{~h}$ after hCG, and reached peak levels $36 \mathrm{~h}$ after hCG administration, just before the expected time of ovulation ( $n=5-6 /$ group). Levels of the primary PGF $2 \alpha$ metabolite (PGFM) were also low at $0 \mathrm{~h}$ hCG. Mean PGFM levels were higher (though not significantly elevated) $12-24 \mathrm{~h}$ after hCG and were highest $36 \mathrm{~h}$ after hCG administration ( $n=5 /$ group). By contrast, $11 \beta$-PGF2 $\alpha$ was not detected in the majority of follicular fluid samples assayed (not shown). No samples obtained $0-12 \mathrm{~h}$ after hCG ( $n=4 /$ time point) and only one out of four samples obtained $24 \mathrm{~h}$ after hCG
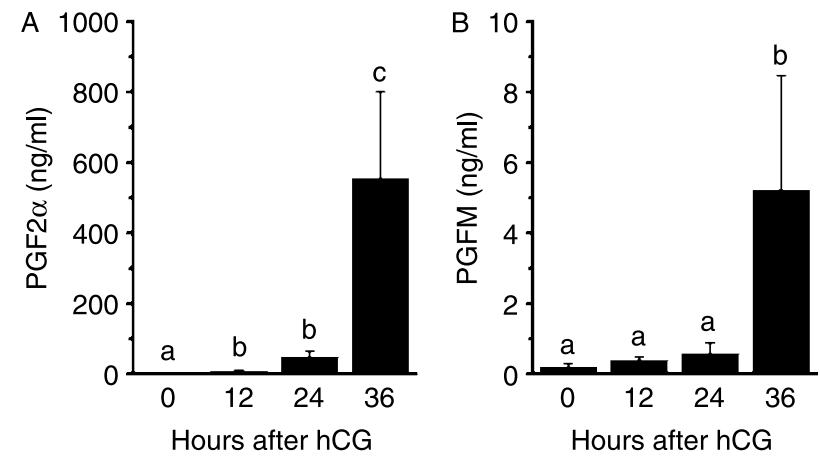

Figure 2 (A) PGF2 $\alpha$ and (B) PGFM levels in monkey follicular fluid. Follicular fluid was obtained from monkeys experiencing controlled ovarian stimulation before $(0 \mathrm{~h})$ and 12,24 , and $36 \mathrm{~h}$ after administration of an ovulatory dose of hCG. PG levels were determined by EIA. Within each figure, groups with different superscripts are different by ANOVA and Newman-Keuls test, $P<0.05$. Data are presented as mean \pm s.E.M., $n=5-6 /$ group.

administration contained detectable $11 \beta$-PGF $2 \alpha$. In follicular fluid samples obtained $36 \mathrm{~h}$ after hCG, three out of five contained detectable $11 \beta$-PGF2 $\alpha$, which in these samples was $6.9 \pm 3.2 \mathrm{ng} / \mathrm{ml}$.

\section{Expression of PGF2 $\alpha$ synthesis enzymes}

AKR1C3 directly converts PGH2 into PGF2 $\alpha$ (Fig. 1). Granulosa cell mRNA levels of $A K R 1 C 3$ were low at $0 \mathrm{~h}$ hCG, intermediate $12 \mathrm{~h}$ after hCG, peaked $24 \mathrm{~h}$ after hCG, and fell to intermediate levels $36 \mathrm{~h}$ after hCG administration (Fig. 3A, $n=4-5$ /group). AKR1C3 protein levels in granulosa cell lysates were assessed by Western blotting. In all monkey granulosa cell lysates examined, AKR1C3 was detected as a single band of $36 \mathrm{kDa}$ (Fig. 3E), consistent with previous detection of a single $36.8 \mathrm{kDa}$ protein in human lung (Suzuki-Yamamoto et al. 1999). Granulosa cell levels of AKR1C3 protein were low at $0 \mathrm{~h}$, rose to intermediate levels $12-24 \mathrm{~h}$ after hCG, and peaked $36 \mathrm{~h}$ after hCG administration (Fig. 3B, $n=4$ /group). AKR1C3 protein was detected in granulosa cells of periovulatory follicles obtained before $(0 \mathrm{~h})$ and at all times after hCG administration by immunohistochemistry (Fig. 4A-C). Stromal cells consistent with identification as theca cells of monkey periovulatory follicles were consistently AKR1C3-negative. AKR1C3 detection in luminal epithelial cells of the monkey seminal vesicle served as a positive control (Fig. 4D).

PGE2 and PGF2 $\alpha$ can be interconverted via the activity of AKR1C1 and AKR1C2 (Fig. 1). Levels of AKR1C1/AKR1C2 mRNA were detectable at 0-12 h after hCG, elevated by $24 \mathrm{~h}$ after hCG, then returned to $0 \mathrm{~h}$ levels by $36 \mathrm{~h}$ after hCG administration (Fig. 3D, $n=4 /$ group). An antibody recognizing monkey AKR1C1 and/or AKR1C2 protein could not be identified, so in situ hybridization with an antisense oligonucleotide probe common to both $A K R 1 C 1$ and $A K R 1 C 2$ mRNA was used 

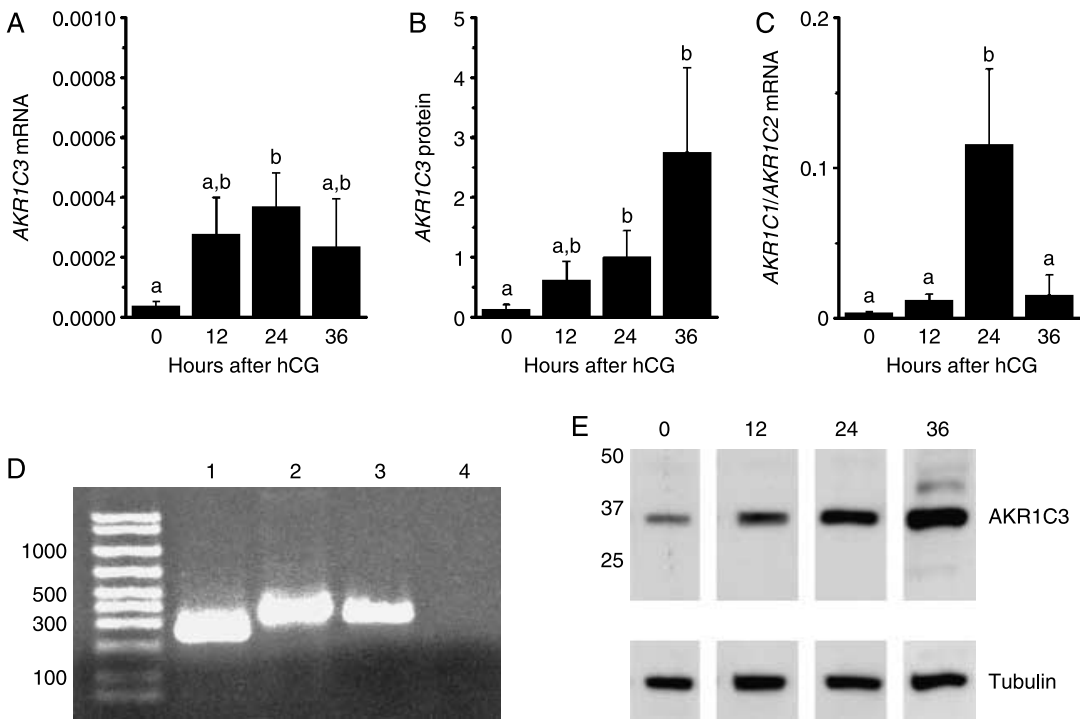

Figure 3 Granulosa cell levels of PGF2 $\alpha$ synthesis enzyme mRNA and protein. Granulosa cells obtained from monkeys experiencing controlled ovarian stimulation before $(0 \mathrm{~h})$ and 12, 24, and $36 \mathrm{~h}$ after $\mathrm{hCG}$ were assessed for (A) AKR1C3 mRNA and (B) protein levels by real-time RT-PCR and Western blotting respectively. (C) Granulosa cell level of mRNA for AKR1C1/AKR1C2 was determined by real-time RT-PCR. (D) Representative gel shows cDNA amplified by real-time RT-PCR representing detection of mRNA for $\beta$-actin (lane 1), AKR1C1/AKR1C2 (lane 2), and AKR1C3 (lane 3) in monkey granulosa cells; negative control is also shown (RT omitted, lane 4). (E) A representative Western blot shows detection of AKR1C3 at 36 kDa in lysates of monkey granulosa cells obtained $0,12,24$, and $36 \mathrm{~h}$ after hCG; detection of tubulin in each sample is also shown. All enzyme mRNA levels were normalized to the level of $\beta$-actin mRNA in the same sample. Western blotting data were normalized to tubulin content of each sample. Within each figure, groups with no common superscripts are different by ANOVA and Newman-Keuls test, $P<0.05$. Data are presented as mean \pm s.E.M., $n=4-5$ /group.

to localize these mRNAs to the cells of the monkey periovulatory follicle (Fig. 4E-G). Dark purple precipitate representing staining for AKR1C1/AKR1C2 mRNA was observed in granulosa cells of monkey ovarian follicles obtained $0,12,24$, and $36 \mathrm{~h}$ after hCG administration. Staining was occasionally noted in the stroma immediately surrounding monkey periovulatory follicles, consistent with the location of theca cells (not shown). However, ovarian stroma located at a distance from follicles was generally devoid of staining for AKR1C1/AKR1C2 mRNA (Fig. 4H). AKR1C1/AKR1C2 mRNA was also detected in small blood vessels (Eyster
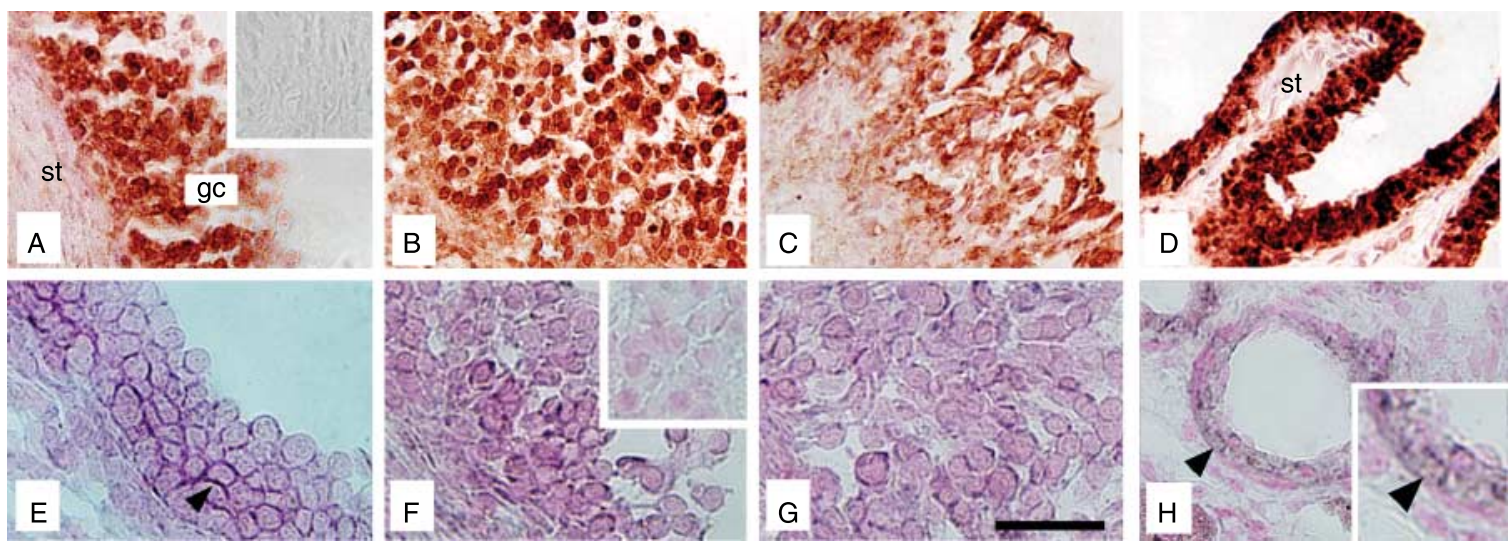

Figure 4 Localization of AKR1C3 protein as well as PGE-F isomerase (AKR1C1/AKR1C2) mRNA to cells of monkey follicles obtained (A and E) 0, 12 (not shown), (B and F) 24, and (C and G) 36 h after hCG administration. All follicles are shown with stroma (st) in lower left, granulosa cells (gc) in central, and the follicle antrum in the upper right of the image. AKR1C3 was detected by immunocytochemistry (red/brown) in granulosa cells of monkey follicles (A-C); stromal cells were consistently devoid of staining. No staining was observed when the primary antibody was omitted (inset, A). Monkey seminal vesicle showed intense immunostaining in the luminal epithelium, but not stroma (st), which served as a positive control (D). Sections in (A-D) were not counterstained. AKR1C1/AKR1C2 mRNA was detected by in situ hybridization in granulosa cells of monkey follicles $(\mathrm{E}-\mathrm{G})$; staining appears dark purple (arrowhead). Inset in (F) shows absence of dark purple staining in granulosa cells when sense probe was used; only nuclear counterstain (pink) is visible. Small vessels in the monkey ovarian stroma stained for AKR1C1/AKR1C2 mRNA (H, arrows) and served as a positive control; ovarian stroma located away from follicles did not stain. An enlarged view of image in $(\mathrm{H}$, inset) shows staining in cells near the vessel lumen. For (A-D), bar in $(\mathrm{G})$ is $50 \mu \mathrm{m}$. For $(\mathrm{E}-\mathrm{H})$, bar in $(\mathrm{G})$ is $25 \mu \mathrm{m}$. Data shown are representative of $n=3-4$ animals/group. 
et al. 2007) within the ovarian stroma, which served as a positive control (Fig. 4H).

\section{Expression of 11 $\beta$-PGF $2 \alpha$ synthesis enzymes}

Production of $11 \beta$-PGF $2 \alpha$ requires the activity of PGD synthase (PGDS) to convert PGH2 into PGD2, then AKR1C3 converts PGD2 into 11 $\beta$-PGF2 $\alpha$ (Fig. 1). Granulosa cells expressed H-PGDS; mRNA levels did not change in response to hCG administration ( $n=4-6 /$ group, data not shown). Similarly, granulosa cells expressed L-PGDS mRNA, but levels were not altered by exposure to an ovulatory dose of hCG ( $n=4$ /group, data not shown).

These data support the identification of two pathways that may produce PGF $2 \alpha$ in the primate periovulatory follicle. AKR1C3 mRNA and protein are expressed in monkey granulosa cells in a manner consistent with the rise in PGF $2 \alpha$ measured in follicular fluid late in the periovulatory interval; previous studies demonstrated that the inducible form of COX2 is expressed by primate granulosa cells to provide PGH2 as substrate for PGF $2 \alpha$ production via AKR1C3 (Duffy \& Stouffer 2001, Duffy et al. 2005b). Granulosa cell expression of AKR1C1/ $A K R 1 C 2 \mathrm{mRNA}$ also increased late in the periovulatory interval, and high follicular fluid levels of PGE2 produced by the PGE synthase mPGES-1 (Duffy et al. 2005a) would provide adequate substrate for PGF2 $\alpha$ production via this enzyme. By contrast, very low levels of $11 \beta$-PGF $2 \alpha$ measured in follicular fluid (above) and granulosa cell cultures (below) argue against a key role for this PG in mediating periovulatory events. Therefore, the following studies focused on PGF2 $\alpha$ production via AKR1C3 and AKR1C1/AKR1C2.

\section{Gonadotropin regulation of PGF2 $\alpha$ synthesis enzyme expression in vitro}

The ovulatory gonadotropin surge increases granulosa cell levels of mRNA for AKR1C3 and AKR1C1/AKR1C2 in vivo (Fig. 3). To determine if hCG acts directly at granulosa cells to modulate expression of these mRNAs, granulosa cells obtained from large periovulatory follicles before $(0 \mathrm{~h})$ administration of hCG were placed in vitro and treated with an ovulatory dose of hCG (Zelinski-Wooten et al. 1997). AKR1C3 mRNA levels were not different between control and hCG-treated granulosa cells after 24 and $48 \mathrm{~h}$ in vitro (Fig. $5 \mathrm{~A}$, $n=4-6$ /group). By contrast, hCG treatment for $24 \mathrm{~h}$ increased expression of mRNA for AKR1C1/AKR1C2 eightfold above mRNA levels measured in control cells (Fig. 5B, $n=5$ /group). After $48 \mathrm{~h}$ in vitro, AKR1C1/ $A K R 1 C 2$ mRNA levels in control and hCG-treated granulosa cells were not different. This pattern of gonadotropin-regulated expression of mRNA for
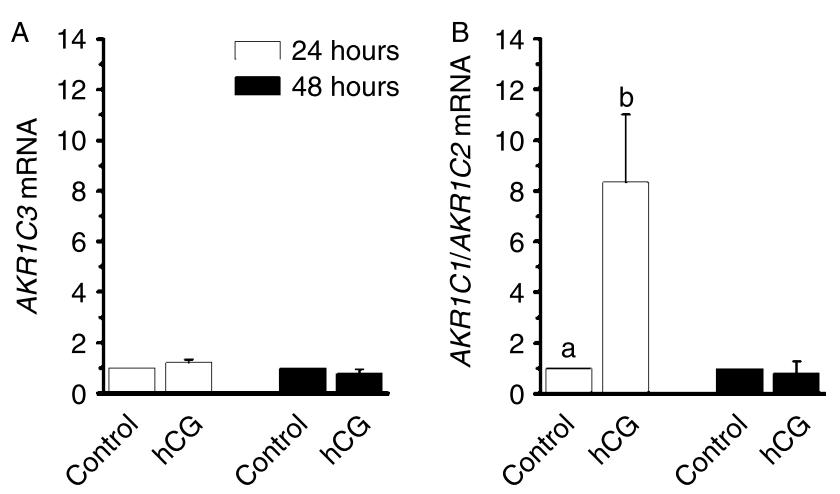

Figure 5 Granulosa cell expression of PGF $2 \alpha$ synthesis enzyme mRNAs in vitro. Granulosa cells obtained from monkeys experiencing ovarian stimulation before administration of hCG were cultured in the absence (control) and presence of hCG (100 ng/ml) for 24 (white bars) or 48 (black bars) $\mathrm{h}$. Total RNA was assessed for (A) AKR1C3 mRNA and (B) AKR1C1/AKR1C2 mRNA by real-time RT-PCR. All enzyme mRNA levels were normalized to the level of $\beta$-actin mRNA in the same sample. Then, mRNA level after hCG treatment was expressed as the fold increase over control cells collected after the same number of hours in vitro. Groups with no common superscripts are different by paired $t$-test, $P<0.05$. Data are presented as mean \pm S.E.M., $n=4-6 /$ group.

$A K R 1 C 1 / A K R 1 C 2$ was very similar to that seen in granulosa cells exposed to hCG in vivo (Fig. 3C).

\section{PGF2 $\alpha$ synthesis enzyme activity in human luteinizing granulosa cells}

The PGF $2 \alpha$ precursor $\mathrm{PGH} 2$ is highly unstable in solution, so AKR1C3 activity was examined by assessing the conversion of PGD2 to $11 \beta$-PGF2 $\alpha$. Human granulosa cells produce very little $11 \beta-\mathrm{PGF} 2 \alpha$ in vitro in the absence of added PGD2 $(3.4 \pm 0.7 \mathrm{pg} / \mathrm{ml}$ media, $n=9)$; media levels of $11 \beta$-PGF $2 \alpha$ were 60 -fold higher in the presence of added PGD2 (Fig. 6A and B). Synthesis of $11 \beta$-PGF2 $\alpha$ from PGD2 was reduced by the AKR1C3 inhibitor medroxyprogesterone acetate (MPA) in a dosedependent manner (Fig. 6A), consistent with the reported IC50 of $0.28 \mu \mathrm{M}$ (Higaki et al. 2003), while the structurally-similar molecule cholesterol had no effect on $11 \beta$-PGF $2 \alpha$ synthesis and served as a negative control (data not shown). To ensure that MPA inhibited AKR1C3 activity independent of the ability of MPA to regulate transcription via the progesterone receptor, additional cells were cultured with MPA and the progesterone receptor antagonist mifepristone (El-Ashry et al. 1989); AKR1C3 activity in the presence of MPA and mifepristone was similar to AKR1C3 activity in the presence of MPA alone (data not shown). As an additional approach, the PG analog bimatoprost was also used to inhibit AKR1C3 activity. Bimatoprost reduced $11 \beta$-PGF2 $\alpha$ production by human luteinizing granulosa cells in a dose-dependent manner (Fig. 6B), consistent with the reported IC50 of $5 \mu \mathrm{M}$ (Koda et al. 2004). 

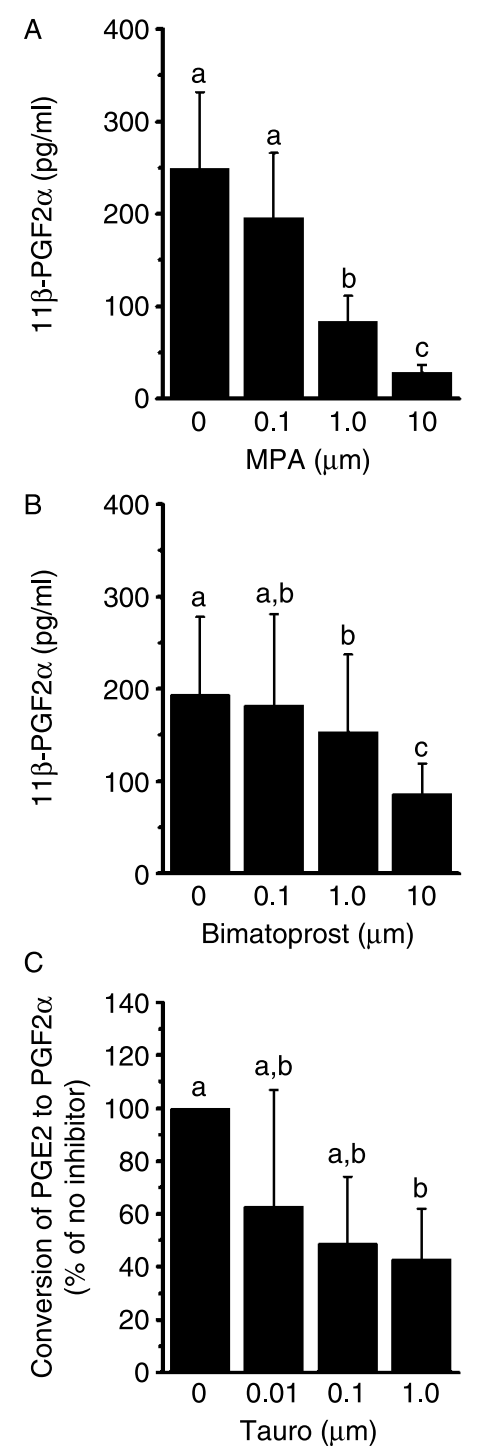

Figure 6 Activity of PGF2 $\alpha$ synthesis enzymes in human luteinizing granulosa cells. (A) Granulosa cells were incubated with the precursor PGD2 alone $(0 \mu \mathrm{M})$ or with the AKR1C3 inhibitor medroxyprogesterone acetate (MPA); media $11 \beta$-PGF $2 \alpha$ concentrations were determined by EIA ( $n=4 /$ group). (B) Granulosa cells were incubated with the precursor PGD2 alone $(0 \mu \mathrm{M})$ or with the AKR1C3 inhibitor bimatoprost; media 11 $\beta$-PGF2 $\alpha$ concentrations were determined by EIA ( $n=4-5 /$ group). (C) To assess AKR1C1 and AKR1C2 activity, human luteinizing granulosa cells were incubated with $\left[{ }^{3} \mathrm{H}\right] \mathrm{PGE} 2$ in the absence $(0 \mu \mathrm{M})$ or presence of the AKR1C2-selective inhibitor taurodeoxycholic acid (Tauro); PGs were separated by thin layer chromatography. Data are expressed as the percentage of total dpms recovered which comigrated with PGF2 $\alpha$ after inhibitor treatment relative to the percentage of total dpms comigrating with PGF $2 \alpha$ in untreated cells ( $n=3-9 /$ group). Within each figure, groups with no common superscripts are different by ANOVA and Newman-Keuls test, $P<0.05$; data are presented as mean \pm s.E.M..

AKR1C1 and AKR1C2 possess bidirectional PGE-F isomerase activity and are capable of converting PGE2 to PGF2 $\alpha$ as well as PGF2 $\alpha$ to PGE2 (Nishizawa et al. 2000). To determine if human luteinizing granulosa cells convert PGE2 to PGF2 $\alpha$, cells were incubated with $\left[{ }^{3} \mathrm{H}\right] \mathrm{PGE} 2$, and production of $\left[{ }^{3} \mathrm{H}\right] \mathrm{PGF} 2 \alpha$ was assessed (Fig. 6C). Granulosa cells converted $9.2 \pm 1.3 \%$ of $\left[{ }^{3} \mathrm{H}\right]$ PGE2 to $\left[{ }^{3} \mathrm{H}\right] \mathrm{PGF} 2 \alpha$ during the $4 \mathrm{~h}$ incubation period. This conversion was inhibited by taurodeoxycholic acid in a dose-sensitive manner, consistent with the reported IC50 for inhibition of AKR1C2 $(0.56 \mu \mathrm{M})$ but not AKR1C1 $(61 \mu \mathrm{M})$ (Bauman et al. 2005). Human luteinizing granulosa cells incubated with $\left[{ }^{3} \mathrm{H}\right] \mathrm{PGF} 2 \alpha$ did not produce $\left[{ }^{3} \mathrm{H}\right] \mathrm{PGE} 2(n=3$, not shown), so the PGE- $F$ isomerase activity in primate granulosa cells is predominantly or exclusively in the direction of PGE2 to PGF2 $\alpha$ and is catalyzed by AKR1C2.

\section{Discussion}

This report is the first to demonstrate that the primate follicle expresses the enzymes and possesses the enzymatic activities required for two pathways of PGF2 $\alpha$ synthesis. Follicular PGF2 $\alpha$ levels peak just before ovulation. PGFM levels in follicular fluid increase in parallel with PGF2 $\alpha$, supporting the concept that the rate of PGF2 $\alpha$ synthesis peaks late in the periovulatory interval. Granulosa cells of the periovulatory follicle contain enzymatic activities capable of PGF2 $\alpha$ production via AKR1C3 (from PGH2) and via AKR1C2 (from PGE2). By contrast, $11 \beta-P G F 2 \alpha$ production via AKR1C3 (from PGD2) is unlikely to contribute to bioactive PGF2 $\alpha$ levels within the follicle. AKR1C3 mRNA and protein reach maximal levels in monkey granulosa cells late in the periovulatory interval, and human granulosa cells obtained just before ovulation possess AKR1C3 activity. AKR1C1/AKR1C2 mRNA peaks just before follicular fluid PGF2 $\alpha$ levels reach maximum levels in monkey follicles, and human granulosa cells obtained just before ovulation can convert PGE2 to PGF2 $\alpha$ via AKR1C2. Taken together, these data support the conclusion that PGF $2 \alpha$ can be produced by the primate periovulatory follicle via two pathways.

Primate granulosa cells likely convert PGH 2 to PGF $2 \alpha$ via AKR1C3, the traditional PGF synthase (Watanabe 2002). AKR1C3 mRNA and protein were detected in periovulatory monkey granulosa cells, and peak AKR1C3 protein levels coincided with peak follicular fluid PGF2 $\alpha$ concentrations. Interestingly, hCG increased granulosa cell $A K R 1 C 3 \mathrm{mRNA}$ level in vivo, but not in vitro, suggesting that elevated $A K R 1 C 3$ expression in vivo may require participation of a nongranulosa cell type, either as the site of gonadotropin action or for the production of a necessary permissive factor. Human luteinizing granulosa cells possess AKR1C3 activity just before ovulation; these cells converted PGD2 to $11 \beta$-PGF2 $\alpha$, and both MPA and bimatoprost reduced $11 \beta$-PGF $2 \alpha$ production. The use of two chemically disparate inhibitors supports the conclusion that these agents act directly at the enzyme to reduce AKR1C3 activity as previously reported (Higaki 
et al. 2003, Koda et al. 2004), not via transcriptional regulation of the $A K R 1 C 3$ gene via the progesterone receptor (in the case of MPA) or the PGF2 $\alpha$ receptor (in the case of bimatoprost). These data represent the first demonstration of gonadotropin-regulated AKR1C3 expression and activity in the mammalian periovulatory follicle and identify granulosa cell AKR1C3 as a possible enzyme involved in follicular PGF2 $\alpha$ synthesis.

AKR1C1 and AKR1C2 are closely related enzymes with PGE-F isomerase activity. Monkey granulosa cell AKR1C1/AKR1C2 mRNA levels increased in response to an ovulatory dose of hCG both in vivo and in vitro, reaching peak levels $24 \mathrm{~h}$ after hCG administration and consistent with the measurement of maximal PGF2 $\alpha$ levels in follicular fluid just before ovulation. While PGE-F isomerase activity can be bidirectional (Nishizawa et al. 2000), only conversion of PGE2 to PGF2 $\alpha$ was detected in human granulosa cells in this study. The AKR1C2-selective inhibitor taurodeoxycholic acid inhibited PGE-F isomerase activity, supporting the conclusion that AKR1C2, but not AKR1C1, is the primary PGE-F isomerase in the primate follicle. Taurodeoxycholic acid $(0.1-1.0 \mu \mathrm{M})$ most likely reduced PGF2 $\alpha$ synthesis through its ability to inhibit PGE-F isomerase activity (Higaki et al. 2003) and not regulation of gene transcription, as similar bile acids regulate transcription with IC50 values of 10-100 $\mu \mathrm{M}$ (Makishima et al. 1999, Parks et al. 1999). Expression and activity of PGE-F isomerase has been reported in whole ovaries and periovulatory follicles from rodents and domestic animals (Murdoch \& Farris 1988, Iwata et al. 1990). In sheep follicles, PGE-F isomerase activity increased in response to an ovulatory gonadotropin surge to peak just before ovulation (Murdoch \& Farris 1988). These previous reports, in combination with data from this study, support a role for the AKR1C2 form of the PGE-F isomerase in the gonadotropin-stimulated conversion of PGE2 to PGF $2 \alpha$ by granulosa cells of the periovulatory follicle.

Despite the presence of two forms of PGDS mRNA as well as AKR1C3 mRNA in monkey granulosa cells, $11 \beta$ PGF2 $\alpha$ levels in follicular fluid were low/nondetectable, suggesting that conversion of $\mathrm{PGH} 2$ to PGD2 and then $11 \beta$-PGF2 $\alpha$ within the periovulatory follicle is inefficient. Therefore, it is unlikely that $11 \beta$-PGF $2 \alpha$ acts via the PGF2 $\alpha$ (FP) receptor to play a major role in ovulation. PGD2 produced within the ovulatory follicle may contribute to periovulatory events by stimulating PGD2 (DP) receptors (Saito et al. 2002). PGD2 is also a precursor for the production of the peroxisome proliferator activated receptor (PPAR) $\gamma$ ligand PGJ2. PPAR $\gamma$ has been implicated in the regulation of periovulatory events such as steroidogenesis (Komar et al. 2001) and granulosa cell apoptosis (Lovekamp-Swan \& Chaffin 2005). While further study regarding the ovulatory role of PGD2 in the primate follicle is warranted, PGD2 does not represent a likely substrate for PGF2 $\alpha$ synthesis.
Many members of AKR enzyme group are multifunctional, capable of both PG and steroid synthesis (Nishizawa et al. 2000). AKR1C3 possesses primarily PG synthesis activity, as this enzyme clearly prefers PG substrates over steroidogenic substrates (Suzuki-Yamamoto et al. 1999, Nishizawa et al. 2000). Both AKR1C1 and AKR1C2 possess PG reductase activity, but AKR1C1 possesses $20 \alpha$-hydroxysteroid dehydrogenase activity while AKR1C2 possesses $3 \alpha$-hydroxysteroid dehydrogenase activity (Nishizawa et al. 2000). Steroid hormones present in the ovarian follicle may reduce the PG reductase activity of AKR1C1 and AKR1C2 during the periovulatory interval. Similarly, PGs may reduce steroid hormone synthesis via members of the AKR enzyme family. The primate periovulatory follicle contains micromolar levels of both PGs and steroid hormones just before ovulation (Chaffin et al. 1999, Duffy \& Stouffer 2001), so determining if the PG synthase activity or the steroid dehydrogenase activity of any individual enzyme predominates in granulosa cells may be exceedingly complex.

While granulosa cells have been established as the primary site of PG synthesis by the periovulatory follicle, a role for theca cells in PG production remains equivocal. $A K R 1 C 3$ mRNA was expressed by isolated human theca cells (Nelson et al. 2001), but AKR1C3 protein was not detected in monkey stroma consistent with theca cells (this study). In situ hybridization localized a sequence common to $A K R 1 C 1$ and $A K R 1 C 2$ mRNA to the stroma of monkey periovulatory follicles in this study. AKR1C1 mRNA and 20 $\alpha$-hydroxysteroid dehydrogenase activity have been reported in human and bovine theca cells (Nelson et al. 2001, Brown et al. 2006), so AKR1C1 is likely the predominant AKR1C in monkey theca. Theca cells produce little PGF $2 \alpha$ in vitro and theca cell PGF $2 \alpha$ synthesis is relatively insensitive to gonadotropin stimulation (Patwardhan \& Lanthier 1981, Wong \& Richards 1991, Duffy et al. 2005a), so theca AKR1C1 may have predominantly steroidogenic activity in periovulatory follicles. While a minor contribution to follicular fluid PGF2 $\alpha$ may be made by theca cells, the gonadotropinstimulated periovulatory rise in follicular fluid PGF2 $\alpha$ is likely due to production primarily, if not exclusively, by granulosa cells.

The specific contribution made by PGF $2 \alpha$ to periovulatory events remains unclear. Administration of PGF2 $\alpha$ to PG-synthesis inhibitor-treated animals can restore ovulation in rodents, domestic animals, and primates (Wallach et al. 1975, Murdoch et al. 1986, Sogn et al. 1987, Janson et al. 1988). However, disruption of FP receptor expression did not prevent ovulation in mice (Sugimoto et al. 1997), arguing against receptormediated action of PGF2 $\alpha$ to initiate ovulatory events in this species. FP receptor mRNA has been detected in follicles of domestic animals and women (Ristimaki et al. 1997, Sayasith et al. 2006, Bridges \& Fortune 2007). FP receptors capable of signal transduction have been 
detected in luteal cells of many species (Davis et al. 1988, Stocco et al. 2003), including monkeys (Houmard et al. 1992); functional FP receptors have also been studied in long-term cultures of human luteinized granulosa cells that serve as an in vitro model for the corpus luteum (Carrasco et al. 1997, Tai et al. 2001). However, it is important to note that the presence of functional FP receptors has never been reported for follicular granulosa cells of any mammalian species. Disruption of the PGE2 receptor EP2 reduces the efficiency of ovulation in mice (Hizaki et al. 1999), and previous studies support a role for PGE2 to regulate periovulatory events in mammals (Sogn et al. 1987, Peters et al. 2004), including primates (Duffy \& Stouffer 2002). It remains possible that either or both PGE2 and PGF2 $\alpha$ may be able to initiate ovulatory events in the follicles of primates and domestic animals. Treatment of PG synthesis inhibitor-treated animals with non-metabolizable EP and FP receptor-selective agonists will likely be required to determine which PG receptors and, therefore, which PG(s), are needed to restore ovulation in these species.

This study identifies two pathways for the synthesis of PGF $2 \alpha$ by the primate periovulatory follicle. As discussed above, a direct role for PGF2 $\alpha$ in periovulatory events will require demonstration of functional FP receptors in the cells of the follicle. As an alternative, PGF2 $\alpha$ may serve as a substrate for the production of ovulatory PGE2 via the PGE-F isomerase activity present in granulosa cells. Finally, PGF2 $\alpha$ synthesis by the periovulatory follicle may function primarily as a metabolic pathway for removal of follicular PGE2 through conversion into PGF2 $\alpha$ via this PGE-F isomerase activity. In this scenario, PGF2 $\alpha$ synthesis may represent a gonadotropin-stimulated mechanism that acts in concert with PGE2 metabolism via PG dehydrogenase activity (Duffy et al. 2005c) to modulate the levels of periovulatory PGE2 within the primate follicle.

\section{Materials and Methods}

\section{Animals}

Granulosa cells, follicular fluid, and whole ovaries were obtained from adult female cynomolgus macaques (Macaca fascicularis) at Eastern Virginia Medical School (EVMS). All animal protocols and experiments were approved by the EVMS Animal Care and Use Committee and were conducted in accordance with the NIH Guide for the Care and Use of Laboratory Animals. Adult females with regular menstrual cycles were maintained as previously described and checked daily for menstruation; the first day of menstruation was designated day 1 of the menstrual cycle (Duffy et al. 2005c). Blood samples were obtained under ketamine chemical restraint $(10 \mathrm{mg} / \mathrm{kg}$ body weight) by femoral or saphenous venipuncture, and serum was stored at $-20{ }^{\circ} \mathrm{C}$. Aseptic surgical procedures (either midline laparotomy or laparoscopy) were performed under isoflurane anesthesia in a dedicated surgical suite.

A controlled ovarian stimulation model developed for the collection of multiple oocytes for in vitro fertilization was used as previously described (Duffy et al. 2005c) to obtain monkey granulosa cells and follicular fluid. Recombinant human follicle-stimulating hormone (r-hFSH; Serono Reproductive Biology Institute, Rockland, MA, USA (90 IU/day) or Organon, a part of Schering Plough Corporation, Roseland, NJ, USA (60 IU/day)) was administered for 6-8 days, followed by administration of $\mathrm{r}$-hFSH plus recombinant human LH (Serono, $60 \mathrm{IU} /$ day) for 2-3 days to stimulate the growth of multiple follicles. The gonadotropin-releasing hormone antagonist Antide ( $0.5 \mathrm{mg} / \mathrm{kg}$ body weight; Serono) was also administered daily to prevent an endogenous ovulatory $\mathrm{LH}$ surge. Adequate follicular development was monitored by serum estradiol levels and ultrasonography (Wolf et al. 1996). Aspiration of follicles at least $4 \mathrm{~mm}$ in diameter or ovariectomy was performed before $(0 \mathrm{~h})$ or 12,24 , and $36 \mathrm{~h}$ after administration of $1000 \mathrm{IU}$ r-hCG (Serono) to induce ovulatory events. To obtain undiluted follicular fluid as well as granulosa cells, each follicle was pierced with a 22-gauge needle, and the aspirated contents of all follicles were pooled.

Whole ovaries were bisected to maintain at least two follicles of at least $4 \mathrm{~mm}$ in diameter on each piece. One piece of ovarian tissue was fixed in $4 \%$ paraformaldehyde and embedded in paraffin; another was coated in OCT compound (Sakura, Torrance, CA, USA), flash frozen in liquid propane, and stored at $-80^{\circ} \mathrm{C}$ until sectioned. Additional monkey tissues such as seminal vesicle were obtained at necropsy and processed as described above.

\section{Monkey granulosa cells}

Monkey granulosa cells and follicular fluid were obtained from follicular aspirates as described previously (Chaffin et al. 1999). Briefly, aspirates were subjected to centrifugation to pellet the oocytes and granulosa cells; the resulting supernatant (i.e., follicular fluid) was removed and stored at $-80{ }^{\circ} \mathrm{C}$. Oocytes were mechanically removed and a granulosa cell-enriched population of the remaining cells was obtained by Percoll gradient centrifugation. Viability of granulosa cell-enriched preparations averaged $80 \%$ as assessed by trypan blue exclusion. The cells were either used immediately for cell culture or were frozen in liquid nitrogen and stored at $-80{ }^{\circ} \mathrm{C}$ for preparation of total RNA or cell lysates.

\section{Human luteinizing granulosa cells}

Human luteinizing granulosa cells were obtained after oocyte removal from follicular aspirates from patients experiencing ovarian stimulation at The Jones Institute for Reproductive Medicine, EVMS. This use of discarded human granulosa cells does not constitute human subjects research as determined by the EVMS Institutional Review Board. No information is obtained regarding an individual patient's diagnosis or treatment protocol. However, most patients receive hCG 34-36 h prior to follicle aspiration, so these human cells are very similar to monkey granulosa cells obtained $36 \mathrm{~h}$ after hCG 
administration. Human granulosa cells were enriched by Percoll gradient centrifugation as described above for monkey granulosa cells.

\section{PG assays}

Follicular fluid obtained from aspirates was acidified and extracted with ethyl acetate prior to assay as previously described (Duffy et al. 2005c). [ $\left.{ }^{3} \mathrm{H}\right]$ PGE2 was added to each sample prior to extraction to correct for procedural losses; the mass of $\left[{ }^{3} \mathrm{H}\right] \mathrm{PGE} 2$ added was $<0.1 \%$ of the total PGE2 content of each follicular fluid sample. Samples were resuspended in assay buffer (see below), and an aliquot was subjected to scintillation counting to calculate PG recovery that averaged $84 \%$. Follicular fluid concentrations of PGF2 $\alpha, 11 \beta$-PGF2 $\alpha$, and the primary PGF2 $\alpha$ metabolite 13,14 -dihydroketo PGF2 $\alpha$ (PGFM) were determined by enzyme immunoassay (EIA; Cayman Chemical, Ann Arbor, MI, USA); the PG content of each sample was corrected based on $\left[{ }^{3} \mathrm{H}\right] \mathrm{PGE} 2$ recovery calculated for each sample. Culture media were assayed without extraction. The intra- and inter-assay coefficients of variation were 12.1 and $18.6 \%, 23.9$ and $6.3 \%$, and 23.0 and $7.0 \%$ respectively for PGF $2 \alpha$ EIA, PGFM EIA, and $11 \beta$-PGF $2 \alpha$ EIA. The lower limit of detection for $11 \beta$-PGF2 $\alpha$ averaged $1.2 \mathrm{ng} / \mathrm{ml}$ after correction for extraction recovery.

\section{Real-time RT-PCR}

Multiple mRNAs were analyzed in each granulosa cell sample by real-time RT-PCR using a Roche LightCycler. Total RNA was obtained from granulosa cells using Trizol reagent (Invitrogen) and was stored at $-80^{\circ} \mathrm{C}$. Total RNA was incubated with DNase and RT was performed as described previously (Chaffin \& Stouffer 1999). PCR was performed using the FastStart DNA Master SYBR Green I kit (Roche) with the exception of L-PGDS, which was amplified using the QuantiTect SYBR Green PCR kit (Qiagen). PCR primers were designed based on the human or monkey sequences using LightCycler Probe Design software (Roche) and nucleotide sequences of monkey PCR products were determined (Microchemical Core Facility, San Diego
State University, CA, USA) (Table 1). Whenever possible, primers span an intron to prevent undetected amplification of genomic DNA. Due to the significant (98\%) nucleic acid identity between human AKR1C1 and AKR1C2 CDNA, PCR primers were designed which shared $100 \%$ identity with both these human cDNAs as well as reported cynomolgus monkey cDNA sequences for AKR1C1 (a monkey AKR1C2 cDNA sequence was not available). At least five log dilutions of the sequenced PCR product was included in each assay and used to generate a standard curve. All data were expressed as the ratio of enzyme mRNA to $\beta$-actin mRNA for each sample. Intraand inter-assay coefficients of variation were less than $10 \%$.

\section{Western blotting for AKR1C3}

Granulosa cells were thoroughly lysed on ice in PBS containing $0.5 \%$ sodium dodecyl sulfate and $0.1 \%$ Triton $X-100$, mixed with denaturing sample buffer, heated to $95^{\circ} \mathrm{C}$ for $10 \mathrm{~min}$, and loaded onto $4-20 \%$ gradient polyacrylamide Tris- $\mathrm{HCl}$ gels (Bio-Rad). Proteins were transferred to PVDF membranes (Immobilon, Millipore, Billerica, MA, USA) and Western blotting proceeded as previously reported (Duffy et al. 2005c). The anti-AKR1C3 primary antibody was a rabbit polyclonal generated against the human AKR1C3 protein (Suzuki-Yamamoto et al. 1999) and was used at a 1:2000 dilution; an anti-rabbit IgG-horseradish peroxidase conjugate secondary antibody (Amersham) was used at a dilution of 1:20 000. A single band of $36 \mathrm{kDa}$ was consistently detected by $\mathrm{ECL}$ (Amersham); no bands were detected when the primary antibody was omitted (not shown). Blots were then stripped of all antibodies following instructions provided by the membrane manufacturer, and Western blotting was performed on the stripped membranes using a mouse anti-tubulin primary antibody (1:1000 dilution, Sigma) and an anti-mouse IgGhorseradish peroxidase conjugate secondary antibody (1:20 000 dilution, Amersham). Molecular size of bands representing AKR1C3 and tubulin proteins were determined by comparison with prestained standards (Bio-Rad). Each experiment included at least four lanes of serial-diluted granulosa cell lysate; detection and densitometric analysis of the protein of interest and tubulin in these samples was used to

Table 1 Reaction conditions for real-time RT-PCR.

\begin{tabular}{|c|c|c|c|c|c|c|}
\hline $\begin{array}{l}\text { Target (primer } \\
\text { concentration) }\end{array}$ & Primer sequences $\left(5^{\prime} \rightarrow 3^{\prime}\right)$ & $\underset{(\mathrm{mM})}{\mathrm{MgCl}_{2}}$ & $\begin{array}{l}\text { Amplified } \\
\text { cDNA (bp) }\end{array}$ & $\begin{array}{l}\text { Percentage identity } \\
\text { between amplified } \\
\text { monkey sequence } \\
\text { and sequence used } \\
\text { for primer design }\end{array}$ & $\begin{array}{l}\text { Accession number } \\
\text { and species of } \\
\text { sequence used for } \\
\text { primer design }\end{array}$ & $\begin{array}{c}\text { Monkey } \\
\text { amplified } \\
\text { fragment } \\
\text { accession } \\
\text { number }\end{array}$ \\
\hline $\begin{array}{l}\text { AKR1C1/AKR1C2 } \\
(0.25 \mu \mathrm{M})\end{array}$ & $\begin{array}{l}\text { Up: GCAATTCCCATCGACC } \\
\text { Down: GCAGAAATCCAGCAGTT }\end{array}$ & 3 & 359 & 95.4 & $\begin{array}{l}\text { NM_001353 } \\
\text { NM_001354 } \\
\text { Human }\end{array}$ & DQ124199 \\
\hline AKR1C3 $(0.25 \mu \mathrm{M})$ & $\begin{array}{l}\text { Up: AGGAACTTTCACCAACAG } \\
\text { Down: CCACCCATCGTTTGTC }\end{array}$ & 3 & 309 & 96.4 & $\begin{array}{l}\text { AB018580 } \\
\text { Human }\end{array}$ & DQ104393 \\
\hline H-PGDS $(0.25 \mu \mathrm{M})$ & $\begin{array}{l}\text { Up: CTGCTCACGTATAATGCG } \\
\text { Down: CTTGAAGGCAACATGG }\end{array}$ & 4 & 267 & 95.8 & $\begin{array}{l}\text { NM_014485 } \\
\text { Human }\end{array}$ & DQ093856 \\
\hline L-PGDS $(0.5 \mu \mathrm{M})$ & $\begin{array}{l}\text { Up: CTACTCATCACACGCTG } \\
\text { Down: GGGTCTCACACTGGTT }\end{array}$ & 4 & 270 & 97.7 & $\begin{array}{l}\text { AB032480 } \\
\text { M. fuscata }\end{array}$ & DQ093857 \\
\hline$\beta$-actin $(0.5 \mu \mathrm{M})$ & $\begin{array}{l}\text { Up: ATCCGCAAAGACCTGT } \\
\text { Down: GTCCGCCTAGAAGCAT }\end{array}$ & 4 & 270 & 97.4 & $\begin{array}{l}\text { NM_001101 } \\
\text { Human }\end{array}$ & AY765990 \\
\hline
\end{tabular}


generate standard curves for semi-quantitative analysis of granulosa cell lysates. Films were scanned and analyzed densitometrically using SigmaGel software (Jandel Scientific, San Rafael, CA, USA). Tubulin levels in granulosa cell lysates were not different between treatment groups. All data are expressed as a ratio of AKR1C3/tubulin content for each granulosa cell sample.

\section{Immunohistochemical detection of AKR1C3}

Immunohistochemical detection of AKR1C3 in ovarian tissues was performed with $5 \mu \mathrm{m}$ sections of paraffin-embedded tissues as previously described (Duffy et al. 2005c) using the anti-AKR1C3 antibody described above for Western blotting (1:500 dilution), a biotinylated bovine anti-rabbit IgG secondary antibody, and peroxide-conjugated avidin solution (ABC kit, Vector Laboratories, Burlingame, CA, USA); peroxidase activity was visualized with Nova Red chromagen (Vector). Omission of the primary antibody served as a negative control.

\section{In situ hybridization}

Primers used for in situ detection of a region common to AKR1C1 and AKR1C2 mRNA (antisense 5'-3' GGGATCACTTCCTCACC; sense 5'-3' GGTGAGGAAGTGATCCC) shared $100 \%$ sequence identity to human $A K R 1 C 1$ and $A K R 1 C 2$. Digoxgenin-labeled oligoprobes were produced using the DIG Oligonucleotide Tailing Kit, 2nd Generation (Roche) according to the manufacturer's protocol. Labeling efficiency was determined by dot blot assay using the DIG Nucleic Acid Detection kit (Roche) according to the manufacturer's protocol. In situ hybridization was performed essentially as described by Dijkman et al. (1995) with prehybridization in a buffer containing $0.3 \mathrm{M}$ sodium chloride, $0.03 \mathrm{M}$ sodium citrate, pH $7.0(2 \times \mathrm{SSC}), 500 \mu \mathrm{g} / \mathrm{ml}$ sheared salmon sperm DNA (Eppendorf, Westbury, NY, USA) denatured for $5 \mathrm{~min}$ at $95^{\circ} \mathrm{C}, 10 \mu \mathrm{g} / \mathrm{ml}$ poly(A) solution (Roche), and $25 \%$ deionized formamide (Sigma). Hybridization of probes with slidemounted frozen ovarian tissue sections was performed using $50 \mathrm{ng} / \mathrm{ml}$ oligoprobe for $2 \mathrm{~h}$ at $55^{\circ} \mathrm{C}$, followed by washing at $55^{\circ} \mathrm{C}$ for $5 \mathrm{~min}$ in $2 \times$ SSC, $1 \times$ SSC, and twice in $0.25 \times$ SSC. Sections were then washed twice for $5 \mathrm{~min}$ in $2 \times$ SSC at room temperature. Immunological detection was performed using the DIG Nucleic Acid Detection kit. Sections were then counterstained with Nuclear Fast Red (Vector) and mounted in glycerol.

\section{Granulosa cell culture}

Granulosa cells were cultured on tissue culture plates coated with fibronectin and maintained at $37{ }^{\circ} \mathrm{C}$ in $5 \% \mathrm{CO}_{2}$ in serumfree DMEM-Ham's F12 medium containing insulin $(2 \mu \mathrm{g} / \mathrm{ml})$, transferrin $(5 \mu \mathrm{g} / \mathrm{ml})$, selenium $(0.25 \mathrm{nM})$, aprotinin $(25 \mathrm{mg} / \mathrm{ml})$, and human low-density lipoprotein $(25 \mu \mathrm{g} / \mathrm{ml})$ as previously described (Duffy \& Stouffer 2003).

For analysis of RNA, monkey granulosa cells were obtained after ovarian stimulation before $(0 \mathrm{~h})$ hCG administration; 100000 cells $/ 400 \mu \mathrm{l}$ media were treated with hCG $(100 \mathrm{ng} / \mathrm{ml}$, Serono) or no treatment (control) for up to $48 \mathrm{~h}$. Cells were lysed in situ with Trizol reagent, and total RNA was prepared with the addition of glycogen $(10 \mu \mathrm{g})$ to improve recovery; RT-PCR was then performed as described above.

\section{AKR1C3 activity}

While PGH2 is unstable in solution, PGD2 is a stable substrate for assay of AKR1C3 activity. Preliminary studies demonstrated that human luteinizing granulosa cells produced very low levels of $11 \beta-P G F 2 \alpha$ in culture $(3.4 \pm 0.7 \mathrm{pg} / \mathrm{ml}$ media). Therefore, AKR1C3 activity was assessed by measuring the conversion of PGD2 to $11 \beta-P G F 2 \alpha$. Granulosa cells were plated $\left(3 \times 10^{5}\right.$ cells $/ \mathrm{ml}$ media) and cultured for $4 \mathrm{~h}$ with vehicles (final concentrations $0.03 \%$ DMSO $+0.04 \%$ ethanol), PGD2 (0.5 $\mu \mathrm{M}$, Cayman), PGD2 + the AKR1C3 inhibitor MPA (Sigma; Higaki et al. 2003), PGD2 + MPA $(10 \mu \mathrm{M})+$ the progesterone receptor antagonist mifepristone (10 $\mu \mathrm{M}$, Sigma; El-Ashry et al. 1989), or PGD2 + the AKR1C3 inhibitor bimatoprost (Cayman; Koda et al. 2004); media were collected and stored at $-20{ }^{\circ} \mathrm{C}$ until assayed for $11 \beta$-PGF2 $\alpha$ concentration by EIA (Cayman). Preliminary experiments (not shown) confirmed that $11 \beta$-PGF2 $\alpha$ production increased linearly with increased PGD2 concentration $(0.01-10 \mu \mathrm{M})$, cell number $\left(1-5.5 \times 10^{5}\right)$, and incubation time $(1-8 \mathrm{~h})$. The concentrations of PGD2, MPA, mifepristone, and bimatoprost used in this study did not alter detection of $11 \beta-P G F 2 \alpha$ by EIA (not shown).

\section{Activity of AKR1C1/AKR1C2}

Human luteinizing granulosa cells were suspended in Hank's buffered salt solution, $\mathrm{pH} 7.4$ (Sigma) $+0.1 \%$ BSA at a concentration of $4 \times 10^{6}$ cells $/ \mathrm{ml}$. Either $\left.{ }^{3} \mathrm{H}\right] \mathrm{PGE} 2$ or $\left[{ }^{3} \mathrm{H}\right] \mathrm{PGF} 2 \alpha$ was added $(0.2 \mu \mathrm{Cu} / \mathrm{ml}$, Perkin-Elmer, Wellesley, MA, USA), and the cells were incubated for $4 \mathrm{~h}$ at $37^{\circ} \mathrm{C}$ in a shaking water bath (Murdoch \& Farris 1988). In each experiment, media $+\left[{ }^{3} \mathrm{H}\right] \mathrm{PG}$ was incubated in the absence of cells to determine the dpms of $\left[{ }^{3} \mathrm{H}\right]$ which comigrated with PGE2 and PGF2 $\alpha$ in the absence of enzymatic conversion. The AKR1C2-selective inhibitor taurodeoxycholic acid (Steraloids, Newport, RI, USA; Bauman et al. 2005) was added to some cells before incubation; vehicle (ethanol, 0.04\%) did not compromise PG synthesis (not shown). After incubation, $\mathrm{HCl}$ was added to achieve a final concentration of $0.1 \mathrm{M}$, and cells + media were extracted with ethyl acetate (Duffy \& Stouffer 2001). The PG-containing organic layer was dried under nitrogen and resuspended in chloroform: methanol (95:5). Radioinert PGE2 and PGF2 $\alpha$ (10 $\mu$ g each) were added to each sample before loading onto silica gel 60 plates (E. Merck) and separated in ethyl acetate: isooctane: glacial acetic acid (100:50:20) (Campbell \& Ojeda 1987). The locations of PGE2 and PGF $\alpha$ in each lane were identified after exposure to iodine vapor. Silica scraped from these portions of the sample lanes was counted in a scintillation counter (LS 6500; Beckman Coulter, Fullerton, CA, USA). To assess conversion of [ $\left.{ }^{3} \mathrm{H}\right] \mathrm{PGE} 2$ to $\left.{ }^{3} \mathrm{H}\right] \mathrm{PGF} 2 \alpha$, dpms comigrating with PGF2 $\alpha$ were expressed as a percentage of the total dpms recovered minus the percentage of total dpms comigrating with PGF2 $\alpha$ when cells were excluded from the reaction. For each patient, percent of dpms representing PGF2 $\alpha$ in the presence of taurodeoxycholic acid was expressed relative to percent of dpms present as 
PGF2 $\alpha$ in absence of the inhibitor. Similar experiments were performed to assess conversion of $\left[{ }^{3} \mathrm{H}\right] \mathrm{PGF} 2 \alpha$ to $\left[{ }^{3} \mathrm{H}\right] \mathrm{PGE} 2$.

\section{Data analysis}

All data were assessed for heterogeneity of variance using Bartlett's test and log-transformed when Bartlett's test yielded a significance of <0.05; data presented in Figs 2, 3, 5B, and 6 were log-transformed before further analysis. Data in Figs 2 and 3 were analyzed by ANOVA, followed by Newman-Keuls test. Data in Fig. 5 were analyzed by two-tailed paired $t$-test. Data in Fig. 6 were analyzed by ANOVA with one repeated measure, followed by Newman-Keuls test. Statistical analyses above were performed using StatPak v4.12 software (Northwest Analytical, Portland, OR, USA). Data are presented as mean \pm S.E.M. and significance was assumed at $P<0.05$.

\section{Acknowledgements}

The authors would like to thank Ms Carrie Seachord for technical assistance and Ms Kim Hester for her role in animal training and animal protocols. Recombinant human gonadotropins and Antide used for these studies were generously provided by Serono Reproductive Biology Institute, Rockland, MA, USA and Organon, a part of Schering-Plough Corporation, Roseland, NJ, USA. These studies were supported by NIH grants HD39872 and HD54691 (DMD) and Eastern Virginia Medical School. The authors declare that there is no conflict of interest that would prejudice the impartiality of this scientific work.

\section{References}

Bauman DR, Rudnick SI, Szewczuk LM, Gophishetty S \& Penning TM 2005 Development of nonsteroidal anti-inflammatory drug analogs and steroid carboxylates selective for human aldo-keto reductase isoforms: potential antineoplastic agents that work independently of cyclooxygenase isozymes. Molecular Pharmacology 67 60-68.

Bridges PJ \& Fortune JE 2007 Regulation, action and transport of prostaglandins during the periovulatory period in cattle. Molecular and Cellular Endocrinology 263 1-9.

Brown KA, Boerboom D, Bouchard N, Dore M, Lussier JG \& Sirois J 2006 Human chorionic gonadotropin-dependent induction of an equine aldoketo reductase (AKR1C23) with 20 $\alpha$-hydroxysteroid dehydrogenase activity during follicular luteinization in vivo. Journal of Molecular Endocrinology 36 449-461.

Campbell WB \& Ojeda SR 1987 Measurement of prostaglandins by radioimmunoassay. Methods in Enzymology 141 323-341.

Carrasco MP, Asboth G, Phaneuf S \& Lopez Bernal A 1997 Activation of the prostaglandin FP receptor in human granulosa cell. Journal of Reproduction and Fertility 111 309-317.

Chaffin CL \& Stouffer RL 1999 Expression of matrix metalloproteinases and their tissue inhibitor messenger ribonucleic acids in macaque periovulatory granulosa cells: time course and steroid regulation. Biology of Reproduction 61 14-21.

Chaffin CL, Hess DL \& Stouffer RL 1999 Dynamics of periovulatory steroidogenesis in the rhesus monkey follicle after controlled ovarian stimulation. Human Reproduction 14 642-649.

Davis JS, Alila HW, West LA, Corradino RA \& Hansel W 1988 Acute effects of prostaglandin F2 alpha on inositol phospholipid hydrolysis in the large and small cells of the bovine corpus luteum. Molecular and Cellular Endocrinology 58 43-50.

Dijkman HBPM, Mentzel S, dejong AS \& Assmann KJM 1995 RNA in situ hybridization using digoxigenin-labeled cRNA probes. Biochemica 2 21-25.
Duffy DM \& Stouffer RL 2001 The ovulatory gonadotrophin surge stimulates cyclooxygenase expression and prostaglandin production by the monkey follicle. Molecular Human Reproduction 7 731-739.

Duffy DM \& Stouffer RL 2002 Follicular administration of a cyclooxygenase inhibitor can prevent oocyte release without alteration of normal luteal function in rhesus monkeys. Human Reproduction 17 2825-2831.

Duffy DM \& Stouffer RL 2003 Luteinizing hormone acts directly at granulosa cells to stimulate periovulatory processes: modulation of luteinizing hormone effects by prostaglandins. Endocrine 22 249-256.

Duffy DM, Seachord CL \& Dozier BL 2005a Microsomal prostaglandin E synthase-1 (mPGES-1) is the primary form of PGES expressed by the primate periovulatory follicle. Human Reproduction 20 1485-1492.

Duffy DM, Seachord CL \& Dozier BL 2005b An ovulatory gonadotropin stimulus increases cytosolic phospholipase A2 (cPLA2) expression and activity in granulosa cells of primate periovulatory follicles. Journal of Clinical Endocrinology and Metabolism 90 5858-5865.

Duffy DM, Dozier BL \& Seachord CL 2005c Prostaglandin dehydrogenase (PGDH) and prostaglandin levels in periovulatory follicles: implications for control of primate ovulation by PGE2. Journal of Clinical Endocrinology and Metabolism 90 1021-1027.

El-Ashry D, Onate SA, Nordeen SK \& Edwards DP 1989 Human progesterone receptor complexed with the antiprogestin RU 486 binds to hormone response element in a structurally altered form. Molecular Endocrinology 3 1545-1558.

Eyster KM, Mark CJ, Gayle R \& Martin DS 2007 The effects of estrogen and testosterone on gene expression in the rat mesenteric arteries. Vascular Pharmacology 47 238-247.

Higaki Y, Usami N, Shintani S, Ishikura S, El-Kabbani O \& Hara A 2003 Selective and potent inhibitors of human $20 \alpha$-hydroxysteroid dehydrogenase (AKR1C1) that metabolizes neurosteroids derived from progesterone. Chemico-Biological Interactions 134-144 503-513.

Hizaki H, Segi E, Sugimoto Y, Hirose M, Saji T, Ushikubi F, Matsuoka T, Noda Y, Tanaka T, Yoshida N et al. 1999 Abortive expansion of the cumulus and impaired fertility in mice lacking the prostaglandin $\mathrm{E}$ receptor subtype EP 2. PNAS 96 10501-10506.

Houmard BS, Guan Z, Stokes BT \& Ottobre JS 1992 Activation of the phosphatidylinositol pathway in the primate corpus luteum by prostaglandin F2 alpha. Endocrinology 131 743-748.

Iwata N, Inazu N \& Satoh T 1990 Changes in rat ovarian carbonyl reductase activity and content during the estrous cycle, and localization. Biology of Reproduction 42 161-166.

Janson PO, Brannstrom M, Holmes PV \& Sogn J 1988 Studies on the mechansim of ovulation using the model of the isolated ovary. Annals of the New York Academy of Sciences 541 22-29.

Koda N, Tsutsui Y, Niwa H, Ito S, Woodward DF \& Watanabe K 2004 Synthesis of prostaglandin $\mathrm{F}$ ethanolamide by prostaglandin $\mathrm{F}$ synthase and identification of Bimatoprost as a potent inhibitor of the enzyme: new enzyme assay method using LC/ESI/MS. Archives of Biochemistry and Biophysics 424 128-136.

Komar CM, Braissant O, Wahli W \& Curry TE Jr 2001 Expression and localization of PPARs in the rat ovary during follicular development and the periovulatory period. Endocrinology 142 4831-4838.

Lovekamp-Swan T \& Chaffin CL 2005 The peroxisome proliferator-activated receptor gamma ligand troglitazone induces apoptosis and p53 in rat granulosa cells. Molecular and Cellular Endocrinology 233 15-24.

Makishima M, Okamoto AY, Repa JJ, Tu H, Learned RM, Luk A, Hull MV, Lustig KD, Mangelsdorf DJ \& Shan B 1999 Identification of a nuclear receptor for bile acids. Science 284 1362-1365.

Murdoch WJ \& Farris ML 1988 Prostaglandin E2-9-ketoreductase activity of preovulatory ovine follicles. Journal of Animal Science 66 2924-2929.

Murdoch WJ, Peterson TA, Van Kirk EA, Vincent DL \& Inskeep EK 1986 Interactive roles of progesterone, prostaglandins, and collagenase in the ovulatory mechanism of the ewe. Biology of Reproduction 35 1187-1194.

Nelson VL, Qin K-N, Rosenfield RL, Wood JR, Penning TM, Legro RS, Strauss JFI \& McAllister JM 2001 The biochemical basis for increased testosterone production in theca cells propagated from patients with polycystic ovary syndrome. Journal of Clinical Endocrinology and Metabolism 86 5925-5933.

Nishizawa M, Nakajima T, Yasuda K, Kanzaki H, Sasaguri Y, Watanabe K \& Ito $\mathbf{S} 2000$ Close kinship of human $20 \alpha$-hydroxysteroid dehydrogenase gene with three aldo-keto reductase genes. Genes to Cells 5 111-125. 
Parks DJ, Blanchard SG, Bledsoe RK, Chandra G, Consler TG, Kliewer SA Stimmel JB, Willson TM, Zavacki AM, Moore DD et al. 1999 Bile acids: natural ligands for an orphan nuclear receptor. Science 284 1365-1368.

Patwardhan VV \& Lanthier A 1981 Prostaglandins PGE and PGF in human ovarian follicles: endogenous contents and in vitro formation by theca and granulosa cells. Acta Endocrinologica 97 543-550.

Peters MW, Pursley JR \& Smith GW 2004 Inhibition of intrafollicular PGE2 synthesis and ovulation following ultrasound-mediated intrafollicular injection of the selective cyclooxygenase-2 inhibitor NS-398 in cattle. Journal of Animal Science 82 1656-1662.

Ristimaki A, Jaatinen R \& Ritvos O 1997 Regulation of prostaglandin F2 $\alpha$ receptor expression in cultured human granulosa-luteal cells. Endocrinology 138 191-195.

Saito S, Tsuda H \& Michimata T 2002 Prostaglandin D2 and reproduction. American Journal of Reproductive Immunology 47 295-302.

Sayasith K, Bouchard N, Dore M \& Sirois J 2006 Molecular cloning and gonadotropin-dependent regulation of equine prostaglandin $\mathrm{F} 2 \alpha$ receptor in ovarian follicles during the ovulatory process in vivo. Prostaglandins and other Lipid Mediators 80 81-92.

Sirois J 1994 Induction of prostaglandin endoperoxide synthase-2 by human chorionic gonadotropin in bovine preovulatory follicles in vivo. Endocrinology 135 841-848.

Sirois J \& Dore M 1997 The late induction of prostaglandin G/H synthase-2 in equine preovulatory follicles supports its role as a determinant of the ovulatory process. Endocrinology 138 4427-4434.

Sogn JH, Curry TE Jr, Brannstrom M, Lemaire WJ, Koos RD, Papkoff H \& Janson PO 1987 Inhibition of follicle-stimulating hormone-induced ovulation by indomethacin in the perfused rat ovary. Biology of Reproduction 36 536-542.

Stocco C, Djiane J \& Gibori G 2003 Prostaglandin F2 $\alpha$ (PGF2 $\alpha$ ) and prolactin signaling: PGF2 $\alpha$-mediated inhibition of prolactin receptor expression in the corpus luteum. Endocrinology 144 3301-3305.

Sugimoto Y, Hasumoto K, Namba T, Irie A, Katsuyama M, Negishi M, Kakizuka A, Narumiya S \& Ichikawa A 1994 Cloning and expression of a cDNA for mouse prostaglandin $\mathrm{F}$ receptor. Journal of Biological Chemistry 269 1356-1360.

Sugimoto Y, Yamasaki A, Segi E, Tsuboi K, Aze Y, Nishimura T, Oida H, Yoshida N, Tanaka T, Katsuyama M et al. 1997 Failure of parturition in mice lacking the prostaglandin F receptor. Science 277 681-683.
Suzuki-Yamamoto T, Nishizawa M, Fukui M, Okuda-Ashitaka E, Nakajima T, Ito S \& Watanabe K 1999 cDNA cloning, expression and characterization of human prostaglandin F synthase. FEBS Letters 462 335-340.

Tai CJ, Kang SK, Choi KC, Tzeng CR \& Leung PCK 2001 Role of mitogenactivated protein kinase in prostaglandin F2 $\alpha$ action in human granulosaluteal cells. Journal of Clinical Endocrinology and Metabolism 86 375-380.

Vane JR, Bakhle YS \& Botting RM 1998 Cyclooxygenases 1 and 2. Annual Review of Pharmacology and Toxicology 38 97-120.

Wallach EE, Bronson R, Hamada Y, Wright KH \& Stevens VC 1975 Effectiveness of prostaglandin F2 $\alpha$ in restoration of hMG-hCG induced ovulation in indomethacin-treated rhesus monkeys. Prostaglandins $\mathbf{1 0}$ 129-138.

Watanabe K 2002 Prostaglandin F synthase. Prostaglandins and other Lipid Mediators 68-69 401-407.

Wolf DP, Alexander M, Zelinski-Wooten MB \& Stouffer RL 1996 Maturity and fertility of rhesus monkey oocytes collected at different intervals after an ovulatory stimulus (human chorionic gonadotropin) in in vitro fertilization cycles. Molecular Reproduction and Development 43 76-81.

Wong WYL \& Richards JS 1991 Evidence for two antigenically distinct molecular weight variants of prostaglandin $\mathrm{H}$ synthase in the rat ovary. Molecular Endocrinology 5 1269-1279.

Zeleznik AJ, Benyo DF, Knobil E \& Neill JD 1994 Control of follicular development, corpus luteum function, and the recognition of pregnancy in higher primates. In The Physiology of Reproduction, pp 751-782. New York: Raven Press, Ltd.

Zelinski-Wooten MB, Hutchison JS, Trinchard-Lugan I, Hess DL, Wolf DP \& Stouffer RL 1997 Initiation of periovulatory events in gonadotrophinstimulated macaques with varying doses of recombinant human chorionic gonadotrophin. Human Reproduction 12 1877-1885.

Received 15 November 2007

First decision 21 January 2008

Revised manuscript received 27 March 2008

Accepted 2 April 2008 